Свєшніков С. В., канд. техн. наук., ст .наук. співроб.

(0000-0001-8924-4535)

Бочарніков В. П., д-р техн. наук, професор

$(0000-0003-4398-5551)$

Полякова О. В.

(0000-0003-4370-2187)

Центр воєнно-стратегічних досліджень Національного університету оборони України імені Івана Черняховського, Київ

\title{
Коронавірус і безпекове середовище: спроба неупередженого аналізу
}

Резюме. У статті автори роблять спробу передбачити можливі наслідки впливу пандемії коронавірусу “КОВІД-19”, а також кризових явищ у світових фінансах і економіці, на зміну ключових умов безпекового середовища.

Ключові слова: коронавірус; безпекове середовище; компаративній аналіз; безпека; конфлікт.

Постановка проблеми. На початку 2020 року людство зіштовхнулося 3 небаченою раніше загрозою - масовим поширенням вкрай вірулентної коронавірусної хвороби з міжнародним позначенням "КОВІД19”. Всесвітня організація з охорони здоров'я швидко визнала епідеміологічну ситуацію пандемією. Майже кожна країна, зокрема i Україна, в своїх безпекових документах передбачала можливість виникнення пандемії. Як правило, така можливість згадувалась в розділі “чорні лебеді" документів стратегічного планування, де описувались явища 3 неструктурованою ймовірністю (за Н. Талебом [1], неструктурована ймовірність не піддається раціональній оцінці, а явища 3 такою ймовірністю можна лише перелічити). Не зважаючи на це, жодна країна не була готовою для боротьби проти поширення хвороби. Найскладніша ситуація виявилась у Китаї, Італії, Іспанії і США, хоча така оцінка $\epsilon$ досить умовною - інші країни також зазнали чималих проблем. Отже практично єдиним, загальноприйнятим способом протидії поширенню хвороби стали розрив транзитних переміщень людей між країнами i навіть внутрішніми регіонами та містами, а також самоізоляція людей, припинення некритичних для життєзабезпечення виробництв, заборона масових заходів, тобто всього, що передбачало масові скупчення людей. Виключенням може бути хіба що Швеція, але й вона запровадила транзитні обмеження на в 'їзд-виїзд.

Усе це звісно стало додатковим гальмом економічних процесів, особливо тих, які залежать від внутрішнього i зовнішнього транзиту: туризм, пасажирські перевезення автомобільним, залізничним i повітряним транспортом, діяльність закладів культури тощо. Поширення “КОВІД-19” певним чином нашарувалось на фінансову кризу на світових фондових ринках і нафтову кризу - різке падіння цін на нафту. Про останнє слід зазначити докладніше. Було б невірним розглядати падіння цін на нафту лише як боротьбу за ринки між провідними видобувними державами. Падіння цін на нафту має системний характер i такі ж системні наслідки, оскільки 3 нафтовидобувною галуззю тісно пов'язані металургія, машинобудування, хімічна промисловість. Падіння нафтових цін призводить до втрати прибутків видобувними компаніями i припинення великих інвестиційних проєктів 3 розвідки енергоносіїв, будівництва нафто- i газопроводів, нафтопереробних $\mathrm{i}$ хімічних заводів, будівництва танкерів. Припинення таких проєктів призводить до гальмування у галузях, розташованих на виробництвах: металургія, важке верстато- i автомобілебудування тощо.

Слід зазначити, що ситуація 3 причинами виникнення “КОВІД-19” дійсно неясна і каламутна. $\mathcal{C}$ кілька вагомих, утім не достатніх, ознак штучності цього штаму коронавірусу. По-перше, Китай на офіційному рівні обвинуватив [2] США у створенні коронавірусу i штучному зараженні китайських громадян. Зі свого боку, Президент США висунув зустрічні обвинувачення i закликав називати коронавірус китайським [3]. Тобто, за фактом обидві країни не відкидають штучність коронавірусу. Можливо, що через важливість питання, до обвинувачень залучились i наукові структури. По-друге, на сьогодні доступність технологій створення штучних генетично модифікованих організмів значно зросла. Якщо технологічні знання, потрібні для створення ядерної зброї завжди були під забороною, то питання біотехнологій активно обговорювались в загальнодоступних 
авторитетних наукових журналах. I no-mpemє, у 2006 році американські вчені зареєстрували патент [4] на коронавірус. В описі патенту зазначається, що спалах цього вірусу було виявлено ще у 2003 році в Китаї, Гонконзі та інших країнах, тобто патент отриманий не на “КОВІД-19”. Утім це означає, що дослідження сімейства коронавірусів проводяться.

Мабуть чітких доказів на користь тієї чи іншої версії не буде ніколи. Проте раптовість виникнення “КОВІД-19”, особливості його географічного поширення, збіг у часі з кризою на фондовому i нафтовому ринках певним чином підтримують виникнення багатьох питань про можливу штучність створення коронавірусу, його навмисне поширення, роль i місце в низці інших кризових явищ. Зазначимо, що майже одразу після виникнення пандемії було висунуто безліч теорій і припущень: від розпилення над Італією розчину 3 малою концентрацією зарину [5] до застосування коронавірусу в американській міжпартійній боротьбі [6] напередодні президентських виборів.

Якщо припустити, що коронавірус створено штучно, певним воєнно-політичним суб'єктом 3 певною метою, на фоні безлічі неоднозначних даних існуе загроза трансформації міркувань в область теорії змови, де будь-яке свідоцтво або судження може бути обернено проти нього самого.

Отже, виникає наступна суперечність: 3 одного боку, характер, час виникнення та інші параметри спостережуваних фактів мають досить тверді підстави стверджувати про наявність невипадкового зв'язку між ними i потребують наукового пояснення; проте 3 іншого боку, складність достовірного розуміння їх природи, значна кількість i багатозначність призводить до міркувань у термінах теорії змови і практично відкидає можливість раціонального наукового розгляду.

Аналіз останніх досліджень i публікацій. Унаслідок новизни пандемії як явища, в наукових виданнях іiі вплив на національну безпеку поки не відображено.

Мета статті полягає у спробі передбачити можливі наслідки впливу пандеміі коронавірусу “КОВІД-19”, а також кризових явищ $\mathrm{y}$ світових фінансах i економіці, на зміну ключових умов безпекового середовища.

Застосований підхід. На наш погляд, припустимий розв'язок зазначеної вище суперечності $\epsilon$ можливим на основі застосування компаративного аналізу - опису i поясненню схожості і розрізнення умов та результатів розвитку великих соціальних систем. Природно, що першим об'єктом компаративного аналізу виступатиме поточна ситуація. Проблема полягає у виборі другого об'єкта, 3 яким вона порівнюватиметься. Оскільки схожих реальних ситуацій 3 історії криз не відомо, залишається обрати гіпотетичну ситуацію - результат мисленого синтезу, отриманий раніше відомим авторитетним автором або авторським колективом. Тоді власне аналіз полягатиме у пошуку схожих рис двох об'єктів і визначенні можливості результату розвитку поточної ситуації, зважаючи на описаний результат розвитку гіпотетичної ситуації.

Залишається надати відповідь, що саме виступатиме другим об'єктом компаративного аналізу? У 2010 році, одразу після закінчення гострої фази фінансово-економічної кризи 2007-2008 років, добре відома аналітична структура “Фонд Рокфеллерів" (“Rockefeller Foundation”) опублікувала доповідь “Сценарії для майбутнього технологічного та міжнародного розвитку" [7]. Доповідь була розроблена на гранти фонду. Серед авторів доповіді близько тридцяти провідних вчених i аналітиків. Сценарії визначають головні, основоположні риси безпекового середовища на період до 2030 року. Хоча опис сценаріїв $є$ досить узагальненим, він цілком припускає порівняння з ними поточної ситуації.

Виклад основного матеріалу. Механізм формування сценаріїв. Головна мета розроблення сценаріїв розвитку майбутнього декларується як визначення ролі технологій на майбутні результати глобалізації. Категорія технології була обрана через іï трансформаційну роль. Автори проводили дослідження за допомогою опитування спеціалістів 3 різноманітних наукових дисциплін, технологічних секторів i географічних регіонів. Головним елементом дослідження було виявлення рушійних сил, характеру та умов їх дій. Сценарії отримувались як результат комбінування сил різними способами. За словами авторів, сценарії не розглядаються як прогнози, це правдоподібні гіпотези, які дають змогу підготуватись до майбутнього, щоб краще його формувати.

Загальним для всіх сценаріїв тенденціями прийнято такі:

підйом Китаю, Індії та інших країн призведе до формування багатополярної глобальної системи; 
зростання світового населення чинитиме тиск на енергетичні ресурси, продовольство i водні ресурси, особливо в країнах, що розвиваються;

прагнення

використовувати поновлювальні енергетичні ресурси, але на досліджуваному часовому горизонті збережеться вплив традиційних енергоносіїв.

На рис. 1 наведено механізм породження сценаріїв, який полягає у комбінуванні двох “критичних невизначеностей": глобальна політична та економічна інтеграція (political and economic alignment) визначається обсягом економічної інтеграції і ефективністю та міцністю політичних структур стосовно глобальних викликів;

спроможність суспільства до адаптації (adaptive capacity) - передбачає ефективне управління структурами та системами для забезпечення стійкості до зовнішніх впливів, характеризується рівнем освіти, толерантністю, відкритими соціальними ліфтами тощо.

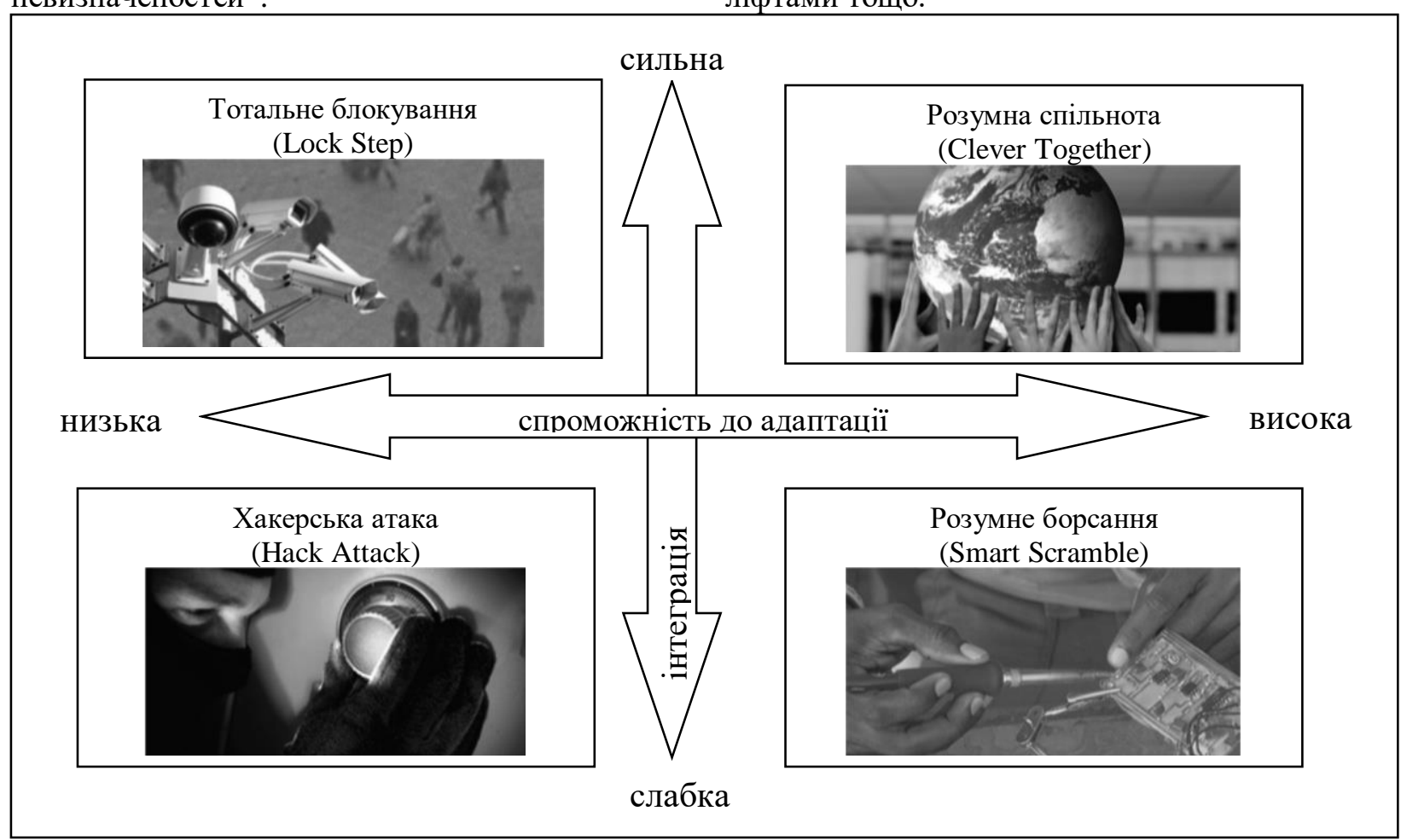

Рис. 1. Породження сценаріїв критичними невизначеностями

Інші невизначеності, які розглядались під час формування сценаріїв, наведено у табл. 1. Вони деталізують і пояснюють критичні невизначеності.

Таблиця 1

Невизначеності, які розглядались під час формування сценаріїв

\begin{tabular}{|c|l|}
\hline Група невизначеностей & \multicolumn{1}{c|}{ Складові групи } \\
\hline \multirow{5}{*}{ Технологічні } & - технології, що найбільше впливають на розвиток \\
& - походження технологічних інновацій, що мають важливе значення для розвитку \\
& (розвинені країни або ті, що розвиваються) \\
& - соціальні та культурні норми \\
& - нові інновації, які значно знижують смертність (вакцини, лікуванн)
\end{tabular}

Коротка характеристика сиенарїв:

сценарій "Тотальне блокування" (сильна інтеграція - низька спроможність суспільства до адаптації) - світ жорсткого державного контролю усіх сфер життєдіяльності 3 
обмеженими технологічними інноваціями та зростаючим незадоволенням громадян;

сценарій "Розумна спільнота" (сильна інтеграція - висока спроможність суспільства до адаптації) - глобалізований, взаємозв'язаний світ з висококоординованими та успішними стратегіями розв'язання світових проблем; сценарій "Хакерська атака" (слабка інтеграція - низька спроможність суспільства до адаптації) - світ послаблених національних урядів, економічно нестабільний і схильний до шоків, 3 процвітаючою злочинністю $\mathrm{i}$ небезпечними технологічними інноваціями;

сценарій "Розумне борсання" (слабка інтеграція - висока спроможність суспільства до адаптації) - розділений та економічно депресивний світ, де окремі спільноти розробляють локальні, ситуативні рішення, неспроможні впоратись зі зростаючим комплексом проблем.

Опис сценаріїв. Оскільки описи сценаріїв у доповіді достатньо об'ємні, розглянемо лише їх ключові, важливі для подальшого аналізу елементи, намагаючись не втратити сенс.

Сценарій “Тотальне блокування”. Унаслідок епідемії нового грипу, більш вірулентного і смертельного, ніж грип H1N1 2009 року, за сім місяців були заражені майже $20 \%$ населення планети i померло 8 млн чоловік. Непропорційно велика кількість людей загинула в Африці, Південно-Східній Азії та Центральній Америці. Протидія розповсюдженню вірусу виявилась проблемою навіть у розвинених країнах, таких як США. Але Китай краще за усіх впорався 3 хворобою завдяки чітким i координованим діям. Унаслідок епідемії транзит людей i товарів було припинено, деякі галузі (зокрема, туризм) також припинили діяльність, світові зв'язки поставок було розірвано.

Національні лідери у всьому світі розширювали свої повноваження i посилювали обмеження та контроль за громадянами. Але після того, як пандемія згасла, цей авторитарний контроль не було скасовано, а було навіть посилено i розповсюджено на ключові галузі економіки. Спочатку такі дії урядів було підтримано суспільством заради більшого успіху i стабільності. Високо розвинуті країни запровадили біометричні паспорти. Нова система обмежень за умов добропорядних лідерів і ефективного управління забезпечила економічне зростання. Проте безвідповідальні еліти використовували владу для задоволення виключно власних інтересів. Повсюдно зріс рівень націоналізму. Сильні обмеження i регулювання стримували розвиток технологій, зменшували обмін ними, що потягнуло зростання технологічної нерівності у світі. Уряди почали диктувати напрями технологічних інновацій, надаючи пріоритет безризиковим технологіям i технологіям у сфері безпеки. Росія та Індія посилили національні стандарти, що не сподобалось США i $\mathrm{CC}$. Транскордонні зв'язки поширилися у формі офіційної допомоги 3 безпеки, а невдалі держави погоджувались на розташування іноземних військових баз для забезпечення безпеки. Але пізніше люди, особливо молодь, почали втомлюватись від обмежень, стали поширюватись громадські заворушення.

Сиенарій "Розумна спільнота". Економічний спад 2007-2008 років не перетворився на тотальну фінансовоекономічну кризу, економічне зростання повернулося, в Китаї та Індії сильно розширився середній клас, зросла урбанізація. Однак зростання було нерівномірним i, крім того, уряди ігнорували екологічні наслідки необмеженого зростання. Потепління, підйом рівня світового океану, інші явища змусили уряди розвинутих країн усвідомити глобальність екологічних проблем, у відповідь на які було реалізовано плани моніторингу та скорочення парникових газів, досягнуто угоду щодо захоплення вуглецю, була створена глобальна система обмежень i торгівлі. Глобальні плани потребували створення глобальних наглядових та управлінських структур не лише у сферах використання енергетичних ресурсів, але у сферах охорони здоров'я і розповсюдження технологій. Такі структури потребували більшої прозорості i, врешті-решт, оброблення більших обсягів даних. Держави поступово втратили частину свого суверенітету. Натомість міжнародні органи і регіональні структури (такі як $\mathrm{OOH}$ i ACEAН) взяли на себе більше відповідальності. Спільними зусиллями вдалося створити ефективні недорогі лікарські сполуки, забезпечити доступ бідніших держав до енергії, водних ресурсів і нових технологій, зокрема, щодо використання сонячної енергії. Проте стрімке економічне зростання породило кризу виробництва продовольства через великий попит, який зростав також експоненціально. Отже стало зрозуміло, що таке зростання не може бути вічним.

Сиенарій “Хакерська атака”. Ланка величезних природних катастроф - 
землетруси, цунамі, посухи - поряд 3 масштабними терористичними актами чинили величезний тиск на вже перенапружену світову економіку, що вступила в рецесію. Брак коштів послаблював уряди держав, які не могли надати адекватну відповідь вимогам безпеки 3 боку своїх громадян. США були змушені фінансувати внутрішні потреби за рахунок перерозподілу оборонних витрат i зменшити військову присутність по регіонах світу. Інші держави теж зосередились на вирішенні внутрішніх проблем і скоротили міжнародні зв'язки і експорт продовольства. Через брак продовольства та інших ресурсів у певних регіонах зросла кількість конфліктів низької інтенсивності. Слабкість урядів призвела до розпаду внутрішнього порядку в державах, особливо з етнічними, релігійними і класовими поділами, зросла інтенсивність сепаратистських рухів, мережева злочинність, незаконна торгівля, виробництво підробок, зокрема ліків. Хакерські напади на корпорації призвели до зростання ролі безпекових технологій (особливо технологій ідентифікації особи) і одночасно - до припинення обміну технологіями. Безпеку забезпечував собі лише той, хто мав гроші. 3 цієї причини по усьому світу стали виникати міські громади закритого типу - своєрідні фортеці. У деяких місцях крах державних можливостей призвів до відродження феодалізму. В інших районах людям вдалося створити більш стійкі громади, що діяли як ізольовані мікроверсії колишніх масштабних систем. Зрештою стерлася відмінність між колишніми розвиненими країнами та країнами, що розвиваються.

$$
\text { Сценарій "Розумне борсання". }
$$

Економічний спад 2007-2008 років не був зупинений. Тягар приватного та державного боргу у світі розвинених країн продовжував пригнічувати економічну активність. Як i раніше, успішність економік держав залежала від експорту на зовнішні ринки. США втратили значну частину власної присутності та авторитету через збільшення боргу, виснаження внутрішнього ринку та неефективний уряд. Китай також зазнав економічної депресії, яка у сукупності 3 екологічними проблемами, змусила його зменшити інвестиції назовні та зосередитись на вирішенні внутрішніх питань. Держави не планували майбутнє, а вирішували проблеми сьогодення. Зросло безробіття і ксенофобія. Виникла i поширилась зворотна міграція. Розподіл добробуту був вкрай нерівномірним. Навіть у країнах, що розвиваються, розрізнення між сільськими i міськими районами збільшилося. Також збільшилось i технологічне розрізнення, люди в бідніших районах стали більш ізольованими. Однак окремі мігранти, що повернулися додому, принесли нові технологічні знання, що дало змогу деяким окремим громадам зміцнити. Виникли клаптикові енергетичні мережі, оазиси промисловості, окремі екосистеми, громади навіть випускали свої валюти. Утім за відсутністю вільних коштів вони не могли масштабувати інновації і сприяти загальному зростанню.

Зазначимо, що головним початковим елементом трьох сценаріїв так чи інакше $\epsilon$ економічне падіння, незважаючи на те, що призвело до нього: пандемія, загострення фінансово-економічної кризи чи ланка природних катаклізмів. За цими сценаріями брак коштів призводить до певної локалізації, уособлення держав i прагнення зосередити зусилля на розв'язанні внутрішніх проблем. Лише другий сценарій - "Розумна спільнота" - передбачає тотальне економічне зростання i, тому, є найбільш позитивним.

Порівняння сиенарїв $i$ поточної cumуauiï. Як бачимо, елементи поточної ситуації присутні в усіх сценаріях. Проте переважна їх кількість певним чином зосереджена у першому сиенаріі - "Тотальне блокування". Більшість початкових елементів сценарію співпадає із сьогоденням майже повністю. Збіг настільки очевидний, що постає питання: це сценарій можливого майбутнього чи попередження про наміри? У розпал пандемії "КОВІД-19” в багатьох державах закрито транскордонні перевезення i значно обмежено навіть внутрішні перевезення. Люди налякані i підтримують режим самоізоляції. Навіть у США наймогутнішій державі - вони вже розуміють кінець минулого образу життя [8] i нічого гарного від майбутнього не чекають [9]. Провідні фінансові структури прогнозують небачене раніше падіння ВВП і глобальну рецесію [10]. Різко зросло безробіття і люди незабаром залишаться без засобів існування. Поширюються повідомлення ЗМІ про напади на магазини, зростання попиту на стрілецьку зброю. В умовах страху за себе, за дітей та їх майбутнє люди стають готовими погодитись 3 будь-якими обмеженнями заради безпеки. Уряди не зволікають перебирати на себе контроль: обмежується вихід людей на вулицю, забороняються демонстрації, мітинги, військові готуються до активнішого втручання [11], розроблюються системи контролю 
місцезнаходження громадян

активізуються розмови про чипізацію.

[12],

За другим сиенарієм - "Розумна спільнота" - поточна ситуація має мало схожих елементів. Навпаки, зважаючи на занепад глобальних систем безпеки i наднаціональних інститутів, який існує на сьогодні, можна припустити, що цей сценарій відкинутий історичним розвитком, принаймні так здається. У цьому контексті, саме як намагання повернути минуле сприймається програмний виступ Г. Кіссінджера [13], де він призвав відновити глобальне управління світом.

Третій сиенарій - "Хакерська атака" має окремі елементи, схожі 3 поточною ситуацією, такі як слабкість окремих урядів, актуалізація безпекових технологій. Однак у сукупності вони не отримали такого поширення у світі, щоб впевнено стверджувати про співпадіння 3 поточною ситуацією. Аналогічного висновку можна дійти стосовно і четвертого сценарію “Розумне борсання".

Якщо припустити, що розвиток поточної ситуації буде за першим сценарієм "Тотальне блокування", людство очікує поширення поліцейських режимів, за яких забезпечуватиметься більш-менш прийнятний добробут населення на тлі великої кількості обмежень політичних і не тільки свобод напрошується аналог післявоєнного СРСР, але не всюди. Багато залежатиме від "якості" правлячих еліт. У випадку безвідповідальної влади такі поліцейські режими можна порівнюватиме з державним беззаконням.

Крім того, людство може очікувати зростання націоналізму. Насамперед це стосується ЄС. Пандемія коронавірусу показала значне послаблення європейської солідарності, про що відверто заявили [14] два колишніх голови Міністерства закордонних справ Німеччини. Відоме європейське аналітичне видання "POLITICO” висловило [15] занепокоєність можливістю “поламки" EC.

Проскиія на безпекове середовище. Зрозуміло, що доповідь “Фонду Рокфеллерів" головну увагу приділяє процесам найвищого концептуального рівня узагальнення, а питання нижчого рівня, зокрема міжнародної безпеки, залишились без деталізаціі. Утім саме вони являють інтерес для України. Отже спробуємо зробити проєкцію глобальних процесів, що складають сценарій “Тотальне блокування" на безпекове середовище, зокрема довкола України.
Як випливає зі сценарію, головними рушійними суб'єктами у сфері безпеки залишаться США, Китай, РФ і СС. Фінансовоекономічна криза, викликана пандемією i об'єктивними обставинами, змусить ці суб' єкти зосередитись на внутрішніх питаннях i посилити авторитарний контроль, маючи на меті, насамперед, забезпечення безпеки громадян, суспільства i держави. Ці країни мають досить розвинутий науково-технічний потенціал, тому припинення обміну технологіями мало вплине на їх технологічний розвиток. Призупинення торгового обміну між суб'єктами (неважливо, чи внаслідок санкцій, чи внаслідок підвищення мита або нетарифних обмежень) неминуче призведе до непотрібності єдиної валюти міжнародних торгових операцій, якою нині $є$ долар. Це логіка процесу. Відмова від єдиної міжнародної валюти стане можливою, коли суб'єкти дійдуть до згоди стосовно списання корпоративних i державних боргів. Вона призведе до вибудовування нових, не обтяжених боргами, прагматичних торгових відносин, оскільки економіки суб'єктів не є самодостатніми. Одні потребують імпорту ресурсів, інші - готових товарів, але головний акцент робитиметься на ресурси. Детальніше ознаки цих процесів описано у [16]. Зі зростанням торгівлі міцнішатимуть й самі суб'єкти.

Оскільки інтереси рушійних суб'єктів завжди сягають поза свої національні кордони, суб'єкти почнуть будувати свої зони впливу. Протидія цьому 3 боку інших суб'єктів буде мало можливою через економічні проблеми i турботу про економічне зростання. Тому слід очікувати домовленості про розділ сфер впливу, як це добре відомо в історії - у критичні моменти великі держави завжди i неодноразово домовлялись про такий розділ і включення спірних земель до тієї чи іншої зони впливу визначалось лише майстерністю дипломатів. Розділ сфер впливу буде знаходитись в основі нової глобальної системи безпеки.

Оскільки турбота суб'єктів про економічне зростання буде визначальним фактором безпекового середовища, можна припустити, що кількість та інтенсивність воєнних конфліктів зменшиться. Їх поновлення можна очікувати тоді, коли певні суб'єкти знов відчуватимуть потребу перегляду зон впливу, a їх економічний розвиток дасть змогу виділити ресурси для ведення воєнного конфлікту. Найбільш можливими місцями виникнення воєнних 
конфліктів будуть лінії розділу зон впливу, зокрема їх ділянки, найбільш критичні для розвитку суб'єктів-конкурентів.

Висновок. 3 огляду на зазначене, стосовно України в найближчому майбутньому слід очікувати послаблення уваги до проблем іï безпеки через підвищення важливості фінансово-економічних питань i питань перебудови міжнародних відносин між провідними суб'єктами. У подальшому, зокрема після досягнення згоди про зони впливу, можна припустити збільшення інтенсивності боротьби довкола визначення напряму воєнно-політичного курсу України.

\section{ПЕРЕЛІК ВИКОРИСТАНОЇ ЛІТЕРАТУРИ}

1. "The Black Swan: The Impact of the Highly Improbable", The New York Times, by Nassim Nicholas Taleb, April 22, $2007 . \quad$ URL: https://www.nytimes.com/2007/04/22/books/chapter s/0422-1st-tale.html (дата звернення: 13.02.2020).

2. Chinese Diplomat Accuses US of Spreading Coronavirus. URL: https://www.voanews.com/ science-health/coronavirus-outbreak/chinesediplomat-accuses-us-spreading-coronavirus

(дата звернення: 13.02.2020).

3. Republicans are using racism against China to try to distract from Trump's disastrous coronavirus response. URL: https://www.businessinsider.com/ trump-using-racism-against-china-to-distract-from-

coronavirus-failures-2020-3 (дата звернення: 13.02.2020).

4. Severe acute respiratory syndrome coronavirus. URL: https://pubchem.ncbi.nlm.nih.gov/patent/ US2006257852 (дата звернення: 13.02.2020).

5. Russia: US Army/Israel using Low Dose Sarin Gas to Supplement CV19 Deaths (updated). URL: https://www.veteranstoday.com/2020/03/22/russiaus-army-israel-using-low-dose-sarin-gas-tosupplement-cv19-deaths/ (дата звернення: 13.02.2020).

6. Coronavirus: Five Trump claims fact-checked. URL: https://www.bbc.com/news/world-us-canada51818627 (дата звернення: 11.02.2020).

7. Scenarios for the Future of Technology and International Development. URL: http://www.nommeraadio.ee/meedia/pdf/RRS/Rocke feller\%20Foundation.pdf (дата звернення: 11.02.2020).
8. For many Americans, the coronavirus pandemic means a normal life is on hold. URL: https://edition.cnn.com/2020/03/12/health/coronaviru s-us-updates-cases-thursday/index.html (дата звернення: 11.02.2020).

9. A report that helped convince Trump to take coronavirus seriously projected that 2.2 million people could die in the US if we don't act. URL: https://www.businessinsider.com/coronavirus-ukreport-projects-2-million-deaths-without-action2020-3 (дата звернення: 11.02.2020).

10. State Shutdowns Have Taken at Least a Quarter of U.S. Economy Offline. URL: https://www.wsj.com/articles/state-coronavirusshutdowns-have-taken-29-of-u-s-economy-offline11586079001 ?mod $=$ searchresults $\&$ page $=1 \&$ pos $=1$ (дата звернення: 15.02.2020).

11. Exclusive: Inside The Military's Top Secret Plans If Coronavirus Cripples the Government. URL: https://www.newsweek.com/exclusive-insidemilitarys-top-secret-plans-if-coronavirus-cripplesgovernment-1492878 (дата звернення: 11.02.2020).

12. В Москве заявили о готовности запустить систему тотального контроля. URL: https://eadaily.com/ru/news/2020/04/04/v-moskvezayavili-o-gotovnosti-zapustit-sistemu-totalnogokontrolya (дата звернення: 11.02.2020).

13. The Coronavirus Pandemic Will Forever Alter the World Order. URL: https://www.wsj.com/articles/ the-coronavirus-pandemic-will-forever-alter-theworld-order-11585953005 (дата звернення: 14.02.2020).

14. The EU is infected with the virus "my country comes first", alarm two former German ministers. URL: https://www.mbs.news/c/2020/04/the-eu-isinfected-with-the-virus-my-country-comes-firstalarm-two-former-german-ministers.html (дата звернення: 14.02.2020).

15. Coronavirus could break the EU. URL: https://www.politico.eu/article/coronavirus-covid19public-health-crisis-could-break-the-eu-europeanunion/ (дата звернення: 14.02.2020).

16. S. Sveshnikov, V. Bocharnikov, V. Pavlenko. The Signs of Changes in the International Relations and Security in Europe. International scientific journal published under the auspices of NATO Defence Education Enhancement Program. 2020. No 1/(12) 1 January. URL: https://www.sdirect24.org/kopianato-deep-no-11 (дата звернення: 10.02.2020).

\section{Стаття надійшла до редакційної колегії 06.04.2020}

\section{Coronavirus and the security environment: an attempt at an unbiased analysis}

\section{Annotation}

At the beginning of 2020, humanity was faced with an unprecedented threat - the massive spread of extremely virulent coronavirus disease with the international designation "COVID-19". The World Health Organization quickly recognized the epidemiological situation as a pandemic. Although a pandemic was contemplated by almost every country, not one of them was ready for it. Almost the only means of counteraction was to reduce the transit movements of people and goods, which immediately led to an economic decline. Therefore, there is a question of anticipating the possible consequences of the impact of a pandemic on changing 
key conditions of security environment. Such a prediction can be tried to be formed on the basis of a comparative analysis of the current situation with a hypothetical situation, which was analyzed by the Rockefeller Foundation back in 2010. The Fund considered four scenarios obtained by combining two critical uncertainties: the level of political and economic integration and the ability of society for adaptation. As a result of a comparative analysis, it was established that the current situation has the greatest number of similar elements with the scenario of total blocking, which involves strengthening the powers of governments, increasing restrictions on people, controlling them, and increasing attention to security issues. The projection of this scenario on the security environment allows us to conclude that in the future we can expect the US, China, the Russian Federation and the EU to retain their ability to influence international relations, to build their own zones of influence, to increase the powers' attention to economic growth, and also to slightly reduce the number and intensity of military conflicts.

Keywords: coronavirus; security environment; comparative analysis; security; conflict. 